\title{
2 Differentiation of Human Monocytes In Vitro: A Model of Macrophage Ontogeny
}

R. Andreesen and M. Kreutz

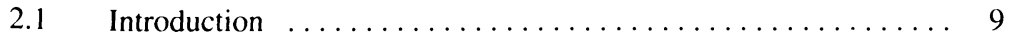

2.2 Mechanisms Generating Macrophage Heterogeneity:

Monocyte Subpopulations and/or Microenvironment ......... 11

2.3 Cell Lines as Model for Monocyte Differentiation ......... 12

$2.4 \quad$ Monocyte Differentiation Induced by Serum ............. 12

2.4.1 Characterization of Differentiation by Phenotype .......... 14

2.4.2 Characterization of Differentiation by Functional Activity ...... 16

2.5 Modulation of Serum-Induced Differentiation ........... 18

2.6 Differentiation Under Serum-Free Conditions ............. 19

2.7 Inhibition of Monocyte Differentiation $\ldots \ldots \ldots \ldots \ldots \ldots 20$

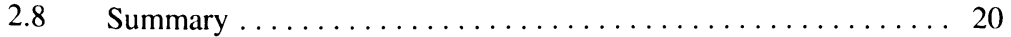

References ................................ 21

\subsection{Introduction}

Monocytes are the common "precursor" of the different types of macrophages which are distributed ubiquitous in all tissues. Monocytes and granulocytes both originate from committed progenitor cells in the bone marrow (colony-forming unit granulocyte-macrophage, CFU-GM). Glycoprotein hormones termed colony-stimulating factors [CSF; macrophage CSF (M-CSF), granulocyte-macrophage CSF (GM-CSF)] or interleukin-3 (IL-3; multi-CSF) regulate the differentiation of this stem cell into monoblasts which then differentiate into promonocytes (Metcalf 1991). The promonocyte divides and gives rise to monocytes which 


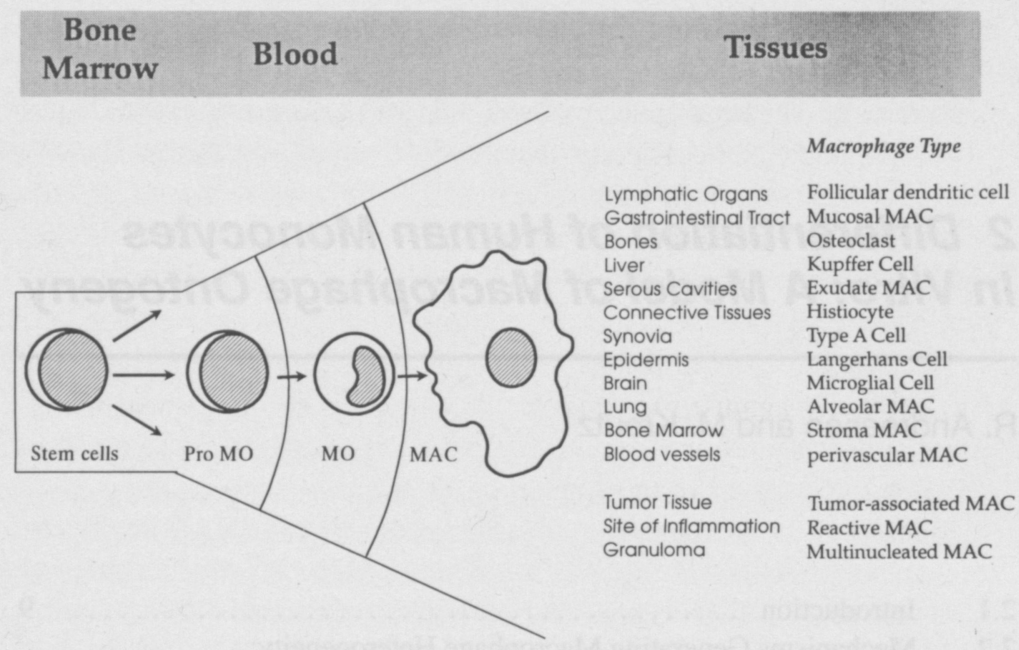

Fig. 1. Schematic description of human macrophage ontogeny

are released into the periphery and circulate for about 2-3 days in the blood stream. Then, upon the action of so far uncharacterized signals, the monocyte leaves the circulation and migrates into tissues and body cavities where it matures into the different types of macrophages, for example, alveolar macrophages in the lung, Kupffer's cells in the liver, and osteoclasts in the bone. Apart from a continuous reconstitution of the various organ subpopulations monocytes also enter infected or malignant tissues as part of the inflammatory response of the host defense system. Here they transform to different forms of reactive histiocytes present, for example, in inflammatory lesions and rejected organ transplants.

Of particular interest and of special importance to the immune surveillance is the ontogeny of tumor-associated macrophages (Mantovani et al. 1992). Here a pivotal role of macrophages becomes evident which is determined by the monocyte to macrophage differentiation process: This results in the generation either of cytotoxic killer cells or of "helper" macrophages appearing as the physiological constituents of the tumor stroma supporting invasive tumor growth and metastasis. A schematic representation of the monocyte differentiation process is shown in 
Fig. 1. The signals controlling this second step in the differentiation process are unknown. In addition to this classical pathway of macrophage generation, macrophages can divide in tissues and thereby also renew their population. The signals controlling macrophage proliferation are not defined but M-CSF seems to play a crucial role. In addition, monocytes and macrophages are important effector cells. They produce a variety of cytokines [e.g., IL-1, IL-6, IL-8, IL-10, tumor necrosis factor- $\alpha($ TNF- $\alpha)$, CSFs, and numerous other factors such as enzyme or reactive oxygen metabolites (Nathan 1987). Other important functions are cytotoxicity against tumor cells, phagocytosis of micro-organisms, and antigen presentation (Johnston and Zucker-Franklin 1988; Unanue and Allen 1987). Most of these functions are dependent on the differentiation and activation stage of monocytes/macrophages.

\subsection{Mechanisms Generating Macrophage Heterogeneity: Monocyte Subpopulations and/or Microenvironment}

Every tissue has its own type of macrophage; because of the similar morphology and their origin from common precursor cells they are summarized as the "mononuclear phagocyte system". Besides the similarity there are many differences between tissue macrophages (Dougherty and McBride 1984). The question is: how is this heterogeneity generated? One possible explanation is the existence of monocyte subpopulations in the blood dependent on clonal variation of myeloid progenitor cells. Different monocyte subpopulations have been described by several groups. Passlick et al. (1989) discriminate between two populations by the expression of the antigens CD14 and CD16 and their different cytokine production (Ziegler-Heitbrock et al. 1992). Subpopulations have also been determined by size and functional activity (Arenson et al. 1980; Wang et al. 1992), HLA-DR expression (Raff et al. 1980), Fc receptor expression (Zembala et al. 1984), and peroxidase activity (Akiyama et al. 1983). However, these differences are more likely explained by different maturation stages of blood monocytes, depending on the circulation time in the blood stream.

Another way of generating different types of macrophages is the dependence on signals in the microenvironment of the tissue. In vitro it has been shown that different types of macrophages are generated from 
monocytes depending on the culture conditions (Munn and Cheung 1990; Ruppert and Peters 1991; Kreutz et al. 1992). Most likely both mechanisms are responsible for macrophage heterogeneity (Rutherford et al. 1993).

\subsection{Cell Lines as Model for Monocyte Differentiation}

A model system for monocyte maturation is the differentiation of monocytic cell lines. Differentiation of the promyelocytic leukemia cell line HL-60 is induced by 1,25-dihydroxyvitamin $\mathrm{D}_{3}\left[1,25(\mathrm{OH})_{2} \mathrm{D}_{3}\right]$ (BarShavit et al. 1983), retinoic acid (Breitmann et al. 1980), dimethylsulfoxide (Collins et al. 1979), deprivation of essential amino acids (Nichols and Weinberg 1989), phorbolester (Cassileth et al. 1981), TNF- $\alpha$ (Weinberg and Larrick 1987), or combinations of these factors (Trinchieri et al. 1987).

Another cell line, the monoblast leukemia line U937 is induced to differentiate in the presence of phorbolester (Liu and $\mathrm{Wu}$ 1992), $1,25(\mathrm{OH})_{2} \mathrm{D}_{3}$ (Dodd et al. 1983), interferon- $\gamma$ (Ralph et al. 1983), or combination of those factors. The differentiation process is followed by the expression of antigens (e.g., CD14), morphology, adherence, or functions such as phagocytosis or lysozyme secretion. These markers are, however, specific for normal monocytes, and therefore this differentiation is comparable to that of monoblasts/promonocytes into monocytes rather than the terminal differentiation of monocytes into macrophages.

\subsection{Monocyte Differentiation Induced by Serum}

The in vitro differentiation of human blood monocytes might serve as a model for the in vivo maturation process of emigrating monocytes. Monocytes which are cultured for 7 days in the presence of human serum differentiate into macrophages (Musson 1983; Andreesen et al. 1983a). In many respects, for example, morphology and functional activity, these cells resemble reactive histiocytes and steady state tissue macrophages. Figure $2 \mathrm{a}$ shows the morphology of freshly isolated mononuclear cells and Fig. 2b mononuclear cells cultured for 7 days in 


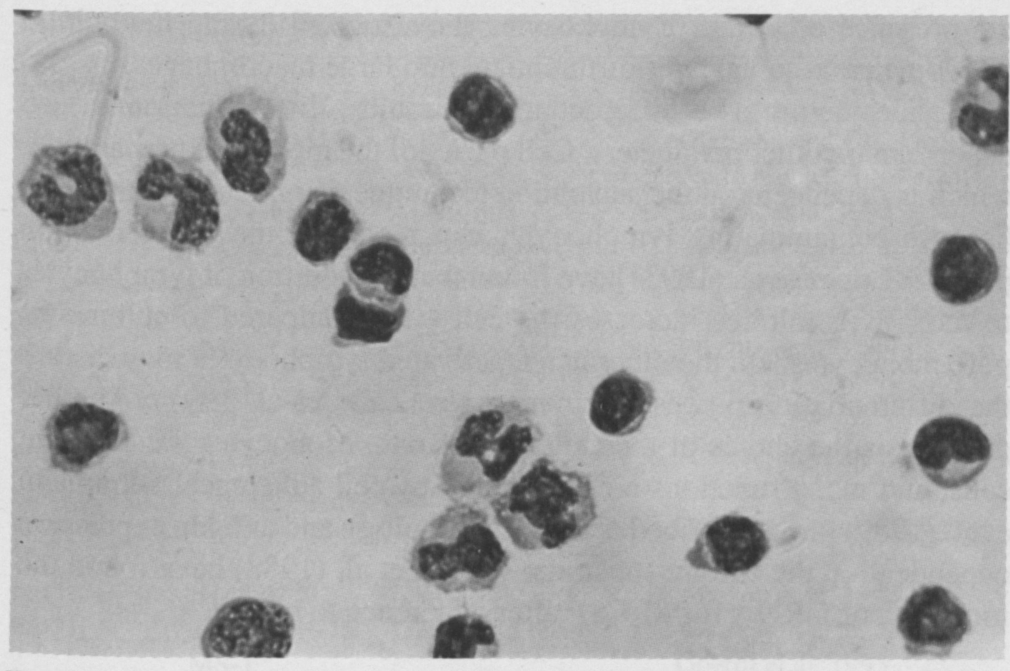

a

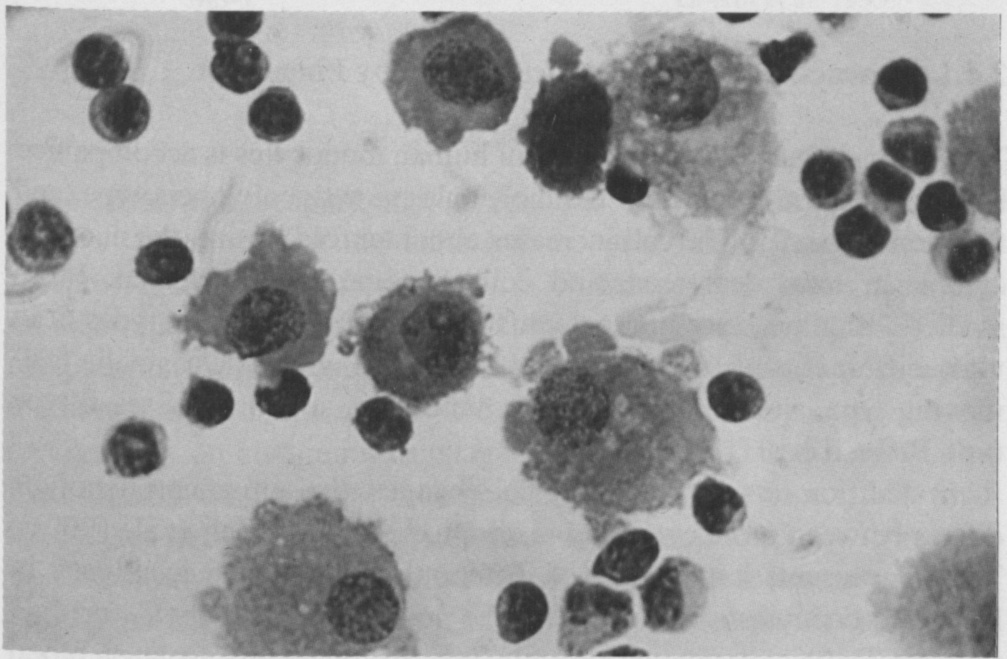

b

Fig. 2a,b. Human mononuclear cells ( 600). a Freshly isolated from peripheral blood. b After 7-day culture with $2 \%$ AB blood group (hydrophobic Teflon foils) 
the presence of serum. Lymphocytes remain small during the culture period whereas monocytes differentiate into large macrophages.

Besides serum as a differentiation stimulus, differentiation is also dependent on other parameters. Cell purity of the monocyte preparation, which is dependent on the separation technique, is one important factor because contaminating lymphocytes can modulate the differentiation process. Lopez et al. (1993) have found that the addition of lymphocytes to monocyte cultures increases the cell yield compared to cultures of pure monocytes. On the other hand, activated lymphocytes may disturb the differentiation process of monocytes (Zaiss et al. 1991). Another problem is the choice of the culture substrate. Monocytes are adherent cells, and many functions are modulated by cell adherence. Schumann et al. (1989) have described distinct morphology and antigen expression dependent on the culture substrate; Haskill et al. (1988) have found the induction of mRNA for M-CSF after adherence to plastic.

\subsubsection{Characterization of Differentiation by Phenotype}

The serum-induced differentiation of human monocytes is accompanied by characteristic changes in the morphology, antigenic phenotype, and functional activity. The cell increases about tenfold in size, the nucleus: cytoplasm ratio decreases, and cells become multinucleated. From studies with time-lapse microcinematography three different types of in vitro differentiated macrophages can be distinguished: a small, fastmoving type, an elongated, slow-moving type, and a round sessil type (von Briesen et al. 1992).

In addition to the morphological changes, the antigenic phenotype differs between monocytes and macrophages (Andreesen et al. 1990a). Table 1 presents a summary of differentiation-associated antigens in human monocytes/macrophages. The low-affinity receptor for IgG (FcIII, CD16) is expressed on only $2 \%-5 \%$ of freshly isolated blood monocytes but is found consistently on in vitro differentiated macrophages and resident liver and spleen macrophages (Clarkson and Ory 1988: Andreesen et al. 1990a). Endoglin, an arginine/glycine/aspartic acid (RGD) containing surface antigen, is also absent from peripheral blood monocytes but is detectable on monocyte-derived macrophages and interstitial macrophages in the red pulp of the spleen (Lastres et al. 
Table 1. Maturation-associated antigens on human macrophages

\begin{tabular}{|c|c|c|c|}
\hline Antigen & Antibody & Function & Reference \\
\hline CD16 & e.g.. GRMI & FcRIII & $\begin{array}{l}\text { Clarkson and Ory } 1988, \\
\text { Andreesen et al. 1990a }\end{array}$ \\
\hline Endoglin & $44 \mathrm{G} 4,8 \mathrm{E} 11$ & Adhesion? & Lastres et al. 1992 \\
\hline CD51 & $13 \mathrm{C} 2,23 \mathrm{C} 6$ & $\begin{array}{l}\text { Vitronectin receptor } \\
\text { ( } \alpha \text {-chain) }\end{array}$ & $\begin{array}{l}\text { Krissansen et al. 1990, } \\
\text { Andreesen et al. 1990a }\end{array}$ \\
\hline gp175 & - & Mannose receptor & Ezekowitz and Stahl 1988 \\
\hline gp86 & $25 \mathrm{~F} 9$ & $?$ & Zwadlo et al. 1985 \\
\hline gp64 & MAX.l & $?$ & $\begin{array}{l}\text { Andreesen et al. } 1986, \\
1988 \mathrm{a}\end{array}$ \\
\hline gp200 & MAX.2 & $?$ & $\begin{array}{l}\text { Andreesen et al. } 1986 . \\
1988 \mathrm{a}\end{array}$ \\
\hline gp68 & MAX.3 & $?$ & $\begin{array}{l}\text { Andreesen et al. } 1986 . \\
1988 \mathrm{a}\end{array}$ \\
\hline gpl 16/46/38 & B148.4 & $?$ & Anegon et al. 1993 \\
\hline CD71 & e.g., MEM-75 & Transferrin receptor & Andreesen et al. 1990a \\
\hline$?$ & MS-1 & $?$ & Goerdt et al. 1993 \\
\hline
\end{tabular}

1992). RGD is a recognition motif for adhesion receptors of the integrin family. A member of the adhesion receptor family, the vitronectin receptor, is also absent from the surface of monocytes but is expressed on macrophages (Andreesen et al. 1990a; Krissansen et al. 1990). This receptor may be involved in apoptosis induction. The mannose receptor, a lectin that mediates uptake and killing of micro-organisms, is expressed only on mature macrophages (Ezekowitz and Stahl 1988). This may explain the fact that macrophages are better effector cells than monocytes in the phagocytosis of micro-organisms.

An unknown $86-\mathrm{kDa}$ protein is recognized by the mouse monoclonal 25F9. Again, monocytes do not express this antigen, but it is found on tissue macrophages such as Kupffer's cells, alveolar macrophages, and monocyte-derived macrophages (Zwadlo et al. 1985). Another set of unknown proteins are recognized by the antibodies of the MAX series. These antigens are absent from monocytes and are expressed on exudate-macrophages from pleural and peritoneal cavity (Andreesen et al. 1988a) and on in vitro differentiated macrophages (Andreesen et al. 1986). The MS-1 antigen is also found on in vitro differentiated mono- 
cytes/macrophages and on dendritic perivascular macrophages in situ (Goerdt et al. 1994). The opposite regulation is found for the human antigen B 18.4, which is highly expressed on monocytes but is lost during the differentiation into macrophages (Anegon et al. 1993). All these antigens are expressed after in vitro differentiation of monocytes with serum and can therefore serve as maturation markers. CD4, an antigen which is involved in infection with the human immunodeficiency virus (HIV), also seems to be expressed at higher density on macrophages; this may explain the finding that macrophages are better targets for HIV than are monocytes (own unpublished results). Other antigens such as the CD14 molecule are found on monocytes as well as on macrophages. The transferrin receptor, CD71 and ICAM-1 (CD54) also are absent from monocytes. However these antigens are also induced under serum-free culture conditions by means of adherence; therefore they are differentiation- but not serum-dependent antigens (Andreesen et al. 1984).

\subsubsection{Characterization of Differentiation by Functional Activity}

Morphology and antigen-phenotype are excellent parameters of the maturation process of monocytes into macrophages. In addition, mature macrophages are characterized by their functional activity. A wellknown activity of macrophages is the destruction of tumor cells. Three types of cytotoxicity have been described: antibody-dependent cellular cytotoxicity (ADCC), direct contact-dependent cytotoxicity, and cytotoxicity mediated by soluble secreted molecules such as TNF- $\alpha$. All three types of cytotoxicity depend on the differentiation stage of macrophages. Munn and Cheung (1989) have found that cultivation of monocytes with M-CSF increases ADCC and contact-dependent cytotoxicity against U937 increased during the maturation of monocytes into macrophages (Andreesen et al. 1983b, 1988b). A soluble mediator of cytotoxicity, a newly described tumoricidal activity termed MCT-170, is secreted only by macrophages (Harwix et al. 1992). The capacity to secrete TNF- $\alpha$ is increased several-fold during the in vitro differentiation of human monocytes; in contrast, the secretion of IL- $1 \beta$ and IL-6 is decreased (Wewers and Herzyk 1989; Scheibenbogen and Andreesen 1991). 
Table 2. Comparison of functional activity in monocytes and macrophages

\begin{tabular}{|c|c|c|c|}
\hline Function & Monocyte & Macrophage & Reference \\
\hline \multicolumn{4}{|l|}{ Cytotoxicity } \\
\hline $\mathrm{ADCC}$ & + & +++ & Munn and Cheung 1989 \\
\hline Antibody independent & + & +++ & Andreesen et al. $1988 \mathrm{~b}$ \\
\hline $\begin{array}{l}\text { Procoagulant activity } \\
\text { secretion }\end{array}$ & - & +++ & Scheibenbogen et al.1992 \\
\hline IL- $1 \beta$ & +++ & $(+)$ & Wewers and Herzyk 1989 \\
\hline IL-6 & +++ & ++ & $\begin{array}{l}\text { Scheibenbogen } \\
\text { and Andreesen } 1991\end{array}$ \\
\hline IL-8 & ++ & ++ & $\begin{array}{l}\text { Scheibenbogen } \\
\text { and Andreesen 1991 }\end{array}$ \\
\hline TNF- $\alpha$ & + & +++ & $\begin{array}{l}\text { Scheibenbogen } \\
\text { and Andreesen 1991 }\end{array}$ \\
\hline $\mathrm{M}-\mathrm{CSF}$ & + & +++ & Scheibenbogen et al.1990 \\
\hline G-CSF, GM-CSF & + & +++ & Krause et al. 1992 \\
\hline Neopterin & + & +++ & Andreesen et al. 1990b \\
\hline 1,25 Vitamin D3 & + & +++ & Kreutz et al. 1993 \\
\hline 24,25 Vitamin D3 & +++ & - & Kreutz et al. 1993 \\
\hline Fibronectin & + & +++ & Yamauchi et al. 1987 \\
\hline Phagocytosis & + & +++ & Jungi and Hafner 1986 \\
\hline \multicolumn{3}{|l|}{ Enzyme activities } & Peters et al. 1987 \\
\hline Nonspecific esterase & ++ & +++ & $\begin{array}{l}\text { Musson et al. } 1980 \text {, } \\
\text { Andreesen et al. } 1983 \mathrm{~b}\end{array}$ \\
\hline $\begin{array}{l}\text { Tartrate-resistant } \\
\text { acid phosphatase }\end{array}$ & - & +++ & Andreesen et al. 1983b \\
\hline Peroxidase & +++ & - & Andreesen et al. 1983b \\
\hline Lysozyme & + & +++ & Andreesen et al. $1983 \mathrm{~b}$ \\
\hline
\end{tabular}

Furthermore, the production of CSFs (M-CSF, G-CSF, GM-CSF; Scheibenbogen et al. 1990; Krause et al. 1992), neopterin (Andreesen et al. 1990b), fibronectin (Yamauchi et al. 1987), tissue factor (Scheibenbogen et al. 1992), and lysozyme (Musson et al. 1980; Andreesen et al. 1983a) is increased during monocyte differentiation. Vitamin D metabolites are also produced by monocytes/macrophages: 24,25 -dihydroxyvitamin $\mathrm{D}_{3}$ is synthesized only by monocytes whereas macrophages release $1,25(\mathrm{OH})_{2} \mathrm{D}_{3}$ (Kreutz et al. 1993). Another important macro- 
phage function is the processing and presentation of antigen to T-lymphocytes. Schlesier et al. have described monocytes as good antigenpresenting cells; however, this capacity decreases when monocytes mature into macrophages (Peters et al. 1987; Schlesier et al. 1992). In contrast, phagocytosis is improved during monocyte differentiation (Jungi und Hafner 1986). Also, enzyme activities are changed during the differentiation of monocytes into macrophages. Peroxidase activity is lost, whereas tartrate-resistant acid phosphatase is induced during monocyte maturation; Nonspecific esterase activity remains constant (Andreesen et al. 1986). A summary of maturation-associated functions is shown in Table 2.

\subsection{Modulation of Serum-Induced Differentiation}

The serum-induced differentiation of monocytes into macrophages can be modulated by supplementing the serum with additional factors. Te Velde et al. (1988) have described phenotypical and functional changes in serum containing monocyte cultures supplemented with IL-4. IL-4 induces HLA-DR expression and a decrease in the release of cytostatic and chemotactic factors compared to control cultures with serum alone. As these features are normally regulated in the opposite way during differentiation, IL-4 seems to inhibit differentiation rather than to induce it. IL-13, another factor produced by CD4-positive T-lymphocytes, also increases HLA-DR expression and induces morphological changes of human monocytes (McKenzie et al.1993).

Apart from the regulation of monocyte generation in bone marrow, CSFs also play a role in the further differentiation process of monocytes into macrophages. Addition of M-CSF and GM-CSF to serum results in a better survival rate and stimulates the capacity for antibody-dependent and antibody-independent cytotoxicity (Suzu et al. 1989; Young et al. 1990; Munn and Cheung 1990; Eischen et al. 1991). In addition, both CSFs regulate the expression of the maturation-dependent vitronectin receptor (Nichilo and Burns 1993). GM-CSF has also been shown to induce CD1 expression on monocytes, a marker which is normally found on thymocytes and Langerhans' cells. This indicates a differentiation in the direction of accessory cells (Kasinrerk et al. 1993). 
$1,25(\mathrm{OH})_{2} \mathrm{D}_{3}$, known to induce the differentiation of monocytic cell lines, also supports the serum-induced differentiation of monocytes. Provvedini et al. (1986) have reported an accelerated differentiation, in terms of increased activity of lysosomal enzymes and enhanced adherence, when monocytes were cultured in the presence of $1,25(\mathrm{OH})_{2} \mathrm{D}_{3}$. In mouse bone marrow macrophages $1,25(\mathrm{OH})_{2} \mathrm{D}_{3}$ and immunoglobulins increased the expression of the maturation-associated mannose-receptor (Clohisy et al. 1987; Schreiber et al. 1991).

\subsection{Differentiation Under Serum-Free Conditions}

It is difficult to identify differentiation-inducing signals when serum is used as medium supplement because serum alone is sufficient to induce maturation of human monocytes. Therefore serum-free culture conditions, for example, serum-free media have been developed by several investigators (Helinski et al. 1988; Vogel et al. 1988; Vincent et al. 1992). Most of those serum-free media contain albumin. In contrast, Akiyama et al. (1988) found no positive effect of albumin on monocyte differentiation, but reported that immunoglobulins can induce differentiation in terms of increased 5' nucleotidase activity and decreased peroxidase activity. $1,25(\mathrm{OH})_{2} \mathrm{D}_{3}$ alone as well as in combination with immunoglobins and albumin is also able to induce monocyte differentiation under serum-free conditions (Kreutz and Andreesen 1990; Kreutz et al. 1992). These cells express differentiation-associated antigens of the MAX series and show functional features of mature macrophages, i.e., high release of TNF- $\alpha$ and neopterin. However, the effect is dependent on the culture substrate; in Teflon culture the addition of immunoglobulin/albumin or M-CSF/albumin is necessary to promote cell survival. Other investigators have also found a positive effect of M-CSF or GM-CSF on cell survival in Teflon cultures (Brugger et al. 1991; Lopez et al. 1993). However, also M-CSF also improve the survival rate on plastic surfaces (Becker et al. 1987). As endogenous $\mathrm{M}$-CSF induction is dependent on cell adherence, monocyte survival in Teflon culture may be diminished because of the weak adherence, for example, an unsufficient induction of endogenous M-CSF. 


\subsection{Inhibition of Monocyte Differentiation}

Differentiation in monocytic cell lines can be induced by cell activators such as interferons and phorbolester. In contrast, the serum-induced differentiation process of blood monocytes is inhibited by activation signals. Interferon- $\gamma$, a typical inducer of monocyte/macrophage activation, suppresses monocyte differentiation antigens and increases HLADR expression (Firestein and Zvaifler 1987; Andreesen et al. 1990a). Two other T-lymphocyte derived cytokines, IL-4 and IL-13, have been reported to induce monocyte differentiation in terms of increased HLADR expression. In addition, cells cultured in the presence of IL-4 are less cytotoxic than control cells, indicating inhibition rather than induction of monocyte differentiation. Therefore, lymphocytes seem to play a crucial role in regulating monocyte differentiation and activation. Another macrophage activator, lipopolysaccharide, is also shown to inhibit monocyte differentiation (Brugger and Andreesen 1991). This indicates that monocyte activation and differentiation seem to be two, noncompatible, mutually exclusive processes.

\subsection{Summary}

Differentiation of human monocytes into macrophages is the central step in the generation of the heterogenous cell family that constitutes the mononuclear phagocyte system. The in vitro maturation of monocytes is a model only for a complex process which involves (a) signals leading to the migration of the monocyte into tissues and (b) signals which determine the characteristic sunpopulation of macrophage given for a given tissue. Furthermore, cells other than monocytes/macrophages or cytokines released by these cells may contribute to the differentiation process. Certainly not all signals which interfere with monocyte differentiation are known; the knowledge of all differentiation-modulating substances would allow the "design" to generate a special type of macrophage in vitro, for example, for tumor cytotoxicity or antigen presentation, for clinical purposes. 


\section{References}

Akiyama Y, Miller PJ, Thurman GB, Neubauer RH, Oliver C, Favilla T, Beman JA, Oldham RK, Stevenson HC (1983) Characterization of a blood monocyte subset with low peroxidase activity. J Clin Invest 72:1093-1 105

Akiyama Y, Griffith R, Miller P, Stevenson GW, Lund S, Kanapa DJ, Stevenson HC (1988) Effects of adherence, activation and distinct serum proteins on the in vitro human monocyte maturation process. J Leukoc Biol 43:224-231

Andreesen R, Picht J, Löhr GW (1983a) Primary cultures of human bloodborn macrophages grown on hydrophobic teflon membranes. J Immunol Methods 56:295-304

Andreesen R, Osterholz J, Bross KJ, Schulz A, Löhr GW (1983b) Cytotoxic effector cell function at different stages of human monocyte-macrophage maturation. Cancer Res 43:5931-5936

Andreesen R, Osterholz J, Bross KJ, Costabel U, Löhr GW (1984) Expression of transferrin receptors and intracellular ferritin during terminal differentiation of human monocytes. Blut 49:195-202

Andreesen R, Bross KJ, Osterholz J, Emmrich F (1986) Human macrophage maturation and heterogeneity: analysis with a newly generated set of monoclonal antibodies to differentiation antigens. Blood 67:1257-1264

Andreesen R, Gadd S, Costabel U, Leser HG, Speth V, Cesnik B, Atkins RC (1988a) Human macrophage maturation and heterogeneity: restricted expression of late differentiation antigens in situ. Cell Tissue Res 253:271279

Andreesen R, Gadd S, Brugger W, Löhr GW, Atkins RC (1988b) Activation of human monocyte-derived macrophages cultured on Teflon: response to interferon-gamma during terminal maturation in vitro. Immunobiology 177:186-198

Andreesen R, Brugger W, Scheibenbogen C, Kreutz M, Leser HG, Rehm A, Löhr GW (1990a) Surface phenotype analysis of human monocyte to macrophage maturation. J Leukoc Biol 47:490-497

Andreesen R, Scheibenbogen C, Kreutz M, Krause S, Rehm A (1990b) Regulation of neopterin secretion during human monocyte to macrophage differentiation in vitro. Pteridines 2:59-61

Anegon I, Blottiere H, Cuturi MS, Lenne, Trinchieri G, Faust J, Perussia B (1993) Characterization of a human monocyte antigen, B 148.4, regulated during cell differentiation and activation. J Leukoc Biol 53:390-398

Arenson BE, Epstein MB, Seeger RC (1980) Volumetric and functional heterogeneity of human monocytes. J Clin Invest 65:613-618 
Bar-Shavit Z, Teitelbaum SL, Reitsma P, Hall A, Pegg LE, Trial J, Kahn AJ (1983) Induction of monocytic differentiation and bone resorption by 1,25dihydroxyvitamin $D_{3}$. Proc Natl Acad Sci USA 80:5907-5911

Becker S, Warren MK, Haskill S (1987) Colony-stimulating factor-induced monocyte survival and differentiation into macrophages in serum-free culture. J Immunol 139:3703-3709

Breitmann TR, Selonick SE, Collins SJ (1980) Induction of differentiation of the human promyelocytic leukemia cell line (HL-60) by retinoic acid. Proc Natl Acad Sci USA 77:2936-2940

Brugger W, Andreesen R (1991) Inhibition of in vitro differentiation of human monocytes to macrophages by lipopolysaccharide (LPS): phenotypic and functional analysis. Int Immunol 3:221-227

Brugger W, Kreutz M, Andreesen R (1991) Macrophage colony-stimulating factor is required for human monocyte survival and acts as a cofactor for their terminal differentiation to macrophages in vitro. J Leukoc Biol 49:483-488

Cassileth PA, Suholet D, Cooper RA (1981) Early changes in phosphatidylcholine metabolism in human acute promyelocytic leukemia cells stimulated to differentiate by phorbol ester. Blood 58:237

Clarkson SB, Ory PA (1988) Developmentally regulated IgG Fc receptors on cultured human monocytes. J Exp Med 167:408-417

Clohisy DR, Bar-Shavit Z, Chappel JC, Teitelbaum S (1987) 1,25-Dihydroxyvitamin D3 modulates bone marrow macrophage precursor proliferation and differentiation. Up-regulation of the mannose receptor. J Biol Chem 262:15922-15929

Collins SJ, Ruscetti FW, Gallagher RE, Gallo RC (1979) Normal functional characteristics of cultured human promyelocytic leukemia cells (HL-60) after induction of differentiation by dimethylsulfoxide. J Exp Med 149:969

Dodd RC, Cohen MS, Newman SL, Gray TK (1983) Vitamin D metabolites change the phenotype of monoblastic U937 cells. Proc Natl Acad Sci USA 80:7538-7541

Dougerty GJ, McBride WH (1984) Macrophage heterogeneity. J Clin Lab Immunol 14:1-11

Eischen A, Vincent F, Bergerat JP, Louis B, Faradji A, Bohbot A, Oberling F (1991) Long-term cultures of human monocytes in vitro. Impact of GMCSF on survival and differentiation. J Immunol Methods 143:209-221

Ezekowitz RAB, Stahl PD (1988) The structure and function of vertebrate mannose lectin-like proteins. J Cell Sci Suppl 9:212-133

Firestein GS, Zvaifler NJ (1987) Down regulation of human monocyte differentiation antigens by interferon. Cell Immunol 104:343-354 
Goerdt S, Bhardway R, Sorg C (1994) Inducible expression of MS-1 high molecular weight protein by endothelial cells of continuous origin and by dendritic cells/macrophages in vivo and in vitro. Am J Pathol (in press)

Harwix S, Andreesen R, Ferber E, Schwamberger G (1992) Human macrophages secrete a tumoricidal activity distinct from tumour necrosis factor- $\alpha$ and reactive nitrogen intermediates. Res Immunol 143:89-94

Haskill S, Johnson C, Eierman D, Becker S, Warren K (1988) Adherence induces selective mRNA expression of monocyte mediators and protooncogenes. J Immunol 140:1690-1694

Helinski EH, Bielat KL, Ovak GM, Pauly JL (1988) Long-term cultivation of functional human macrophages in teflon dishes with serum-free media. $\mathbf{J}$ Leukoc Biol 44:111-121

Johnston RB, Zucker-Franklin D (1988) The mononuclear phagocyte system. In: Zucker-Franklin D, Greaves MF, Grossi CE, Marmont AM (eds) Atlas of blood cells: function and pathology. Fischer, Stuttgart

Jungi TW, Hafner S (1986) Quantitative assessment of Fc receptor expression and function during in vitro differentiation of human monocytes to macrophages. Immunology 58:131-137

Kasinrerk W, Baumruker T, Majdic O, Knapp W, Sockinger H (1993) CDI molecule expression on human monocytes induced by granulocyte-macrophage colony-stimulating factor. J Immunol 150:579-589

Krause SW, Kreutz M, Zenke G, Andreesen R (1992) Developmental regulation of granulocyte-macrophage colony-stimulating factor production during monocyte-to-macrophage maturation. Ann Hematol 64:190-195

Kreutz M, Andreesen R (1990) Induction of human monocyte into macrophage maturation by 1,25-dihydroxyvitamin $D_{3}$. Blood 76:2457-2461

Kreutz M, Krause SW, Hennemann B, Rehm A, Andreesen R (1992) Macrophage heterogeneity and differentiation: defined serum-free culture conditions induce different types of macrophages in vitro. Res Immunol 143:107-115

Kreutz M, Andreesen R, Krause SW, Ritz E, Reichel H (1993) 1,25-Dihydroxyvitamin D3 production and vitamin D3 receptor expression are developmentally regulated during differentiation of human monocytes into macrophages. Blood 82:1300-1307

Krissansen GW, Elliot MJ, Lucas CM, Stomski FC, Berndt MC, Cheresh DA, Lopez AF, Burnes GF (1990) Identification of a novel integrin $\beta$ subunit expressed on cultured monocytes (macrophages). J Biol Chem 265:823-830

Lastres P, Bellon T, Cabanas C, Sanchez-Madrid F, Acevedo A, Gougos A, Letarte M, Bernabeu C (1992) Regulated expression on human macrophages of endoglin, an Arg-Gly-Asp-containing surface antigen. Eur J Immunol 22:393-397 
Liu M, Wu M (1992) Induction of human monocyte cell line U937 differentiation and CSF-1 production by phorbol ester. Exp Hematol 20:974-979

Lopez M, Martinache C. Canepa S, Chokri M, Scotto F, Bartholeyns J (1993) Autologous lymphocytes prevent the death of monocytes in culture and promote as do GM-CSF, IL-3 and M-CSF, their differentiation into macrophages. J Immunol Methods 159:29-38

Mantovani A, Bottazzi B, Colotta F, Sozzani S, Ruco L (1992) The origin and function of tumor-associated macrophages. Immunol Today 13:265-270

McKenzie ANJ, Culpepper JA, de Waal Malefyt R, Briere F, Punnonen J, Aversa G, Sato A, Dang W, Cocks BG, Menon S, de Vries JE, Banchereau J, Zurawski G (1993) Interleukin 13, a T-cell-derived cytokine that regulates human monocyte and B-cell function. Proc Natl Acad Sci USA 90:3735-3739

Metcalf D (1991) Control of granulocytes and macrophages: molecular, cellular and clinical aspects. Science 254:529-533

Munn DH, Cheung NV (1989) Antibody-dependent antitumor cytotoxicity by human monocytes cultured with recombinant macrophage colony-stimulating factor. J Exp Med 170:511-526

Munn DH, Cheung NV (1990) Phagocytosis of tumor cells by human monocytes cultured in recombinant macrophage colony-stimulating factor. J Exp Med 172:231-237

Musson RA (1983) Human serum induces maturation of human monocytes in vitro. Changes in cytolytic activity, intracellular lysosomal enzymes, and nonspecific esterase activity. Am J Physiol 111:331-340

Musson RA, Shafran H, Henson PM (1980) Intracellular levels and stimulated release of lysosomal enzymes from human peripheral blood monocytes and monocyte-derived macrophages. J Reticoendothel Soc 28:249-264

Nathan CF (1987) Secretory products of macrophages. J Clin Invest 79:319-323

Nichilo MO, Burns GF (1993) Granulocyte-macrophage and macrophage colony-stimulating factors differentially regulate $\alpha v$ integrin expression on cultured human macrophages. Proc Natl Acad Sci USA 90:2517-2521

Nichols KE, Weinberg JB (1989) Essential amino acid deprivation induces monocytic differentiation of the human HL-60 myeloid leukemia cell line. Blood 73:1298-1306

Passlick B. Flieger D. Ziegler-Heitbrock HWL (1989) Identification and characterization of a novel monocyte subpopulation in human peripheral blood. Blood 74:2527-2534

Peters JH, Ruhl S, Friedrichs D (1987) Veiled accessory cells deduced from monocytes. Immunobiology 176:154-166

Provvedini DM, Deftos LJ, Manolagas SC (1986) 1,25-Dihydroxyvitamin $\mathrm{D}_{3}$ promotes in vitro morphological and enzymatic changes in normal human 
monocytes consistent with their differentiation into macrophages. Bone 7:23-28

Raff HV, Picker LJ, Stobo JD (1980) Macrophage heterogeneity in man. A subpopulation of HLA-DR bearing macrophages required for antigen-induced $\mathrm{T}$ cell activation also contains stimulators for autologous-reactive $\mathrm{T}$ cells. J Exp Med 152:581-593

Ralph P, Harris PE, Punjabi CJ, Welte K, Litcofsky PB, Ho MK, Rubin BY, Moore MAS, Springer TA (1983) Lymphokine inducing "terminal differentiation" of the human monoblast leukemia line U937: a role for $\gamma$-interferon. Blood 62:1169-1175

Rutherford MS, Witsell A, Schook LB (1993) Mechanisms generating functionally heterogeneous macrophages:chaos revisited. J Leukoc Biol 53:602-618

Ruppert J, Peters JH (1991) IL-6 and IL-1 enhance the accessory activity of human blood monocytes during differentiation to macrophages. J Immunol 146:144-149

Scheibenbogen C, Andreesen R (1991) Developmental regulation of the cytokine repertoire in human macrophages: IL-1, IL-6, TNF-alpha and M-CSF. J Leukoc Biol 50:35-42

Scheibenbogen C, Zenke G, Faggs B, Motoyoshi K, Kanz L, Sawert H, Brugger W, Andreesen R (1990) Secretion of colony-stimulating factor for macrophages (M-CSF) and granulocyte/macrophages (GM-CSF) is developmentally regulated in human macrophages. In: Freund M, Link H, Welte $\mathrm{K}$ (eds) Cytokines in heopoisis, oncology and aids. Springer, Berlin Heidelberg New York, pp 45-51

Scheibenbogen C, Moser H, Krause SW, Andreesen R (1992) Interferongamma-induced expression of tissue factor activity during human monocyte to macrophage maturation. Haemostasis 22:173-178

Schlesier M, Krause S, Dräger R, Wolff-Vorbeck G, Kreutz M, Andreesen R (1992) Differential response of the autoreactive T-cell clone UA-S2 to different autologous stimulator cells. International congress of immunology, Budapest, p 336 (W56-42, abstract)

Schreiber RS, Blum JS, Stenson WF, MacDermott RP, Stahl PD, Teitelbaum SL, Perkins SL (1991) Monomeric IgG2 $\alpha$ promotes maturation of bonemarrow macrophages and expression of the mannose receptor. Proc Natl Acad Sci USA 88:1616-1620

Schumann RR, van der Bosch J, Rüller S, Ernst M, Schlaak M (1989) Monocyte long-term cultivation on microvascular endothelial cell monolayers: morphological and phenotypic characterization and comparison with monocytes cultured on tissue culture plastic. Blood 73:818-826 
Suzu S, Yokota H, Yamada M, Yanai N, Saito M, Kawashima T, Saito M, Takaku F, Motoyoshi K (1989) Enhancing effect of human monocytic colony-stimulating factor on monocyte tumoricidal activity. Cancer Res 49:5913-5917

Te Velde AA, Klomp JPG, Yard BA, de Vries JE, Figdor CG (1988) Modulation of phenotypic and functional properties of human peripheral blood monocytes by IL-4. J Immunol 140:1548-1553

Trinchieri G, Rosen M, Perussia B (1987) Retinoic acid cooperates with tumor necrosis factor and immune interferon in inducing differentiation and growth inhibition of the human promyelocytic leukemic cell line HL-60. Blood 69:1218-1224

Unanue ER, Allen PM (1987) The basis for the immunoregulatory role of macrophages and other accessory cells. Science 236:551-557

Vincent F, Eischen A, Bergerat JP, Faradji A, Bohbot A, Oberling F (1992) Human blood-derived macrophages: differentiation in vitro of large quantity of cells in serum-free medium. Exp Hematol 20:17-23

Vogel SN, Perera PY, Hogan MM, Majde JA (1988) Use of serum-free, compositionally defined medium for analysis of macrophage differentiation in vitro. J Leukoc Biol 44:136-142

Von Briesen H, Sander U, Seack KH, Kreutz M, Becker K, Müller S, Rübsamen-Waigmann H, Andreesen R (1992) HIV-induced syncytia formation in human monocytes/macrophages: a microcinematographic study. Pathobiology 60 [Suppl 1]:1-38

Wang SY, Mak KL, Chen LY, Chou MP, Ho CK (1992) Heterogeneity of human blood monocyte: two subpopulations with different sizes, phenotypes and functions. Immunology 77:298-303

Weinberg JB, Larrick JW (1987) Receptor-mediated monocytoid differentiation of human promyelocytic cells by tumor necrosis factor: synergistic actions with interferon and 1,25-dihydroxyvitamin D3. Blood 70:994-1002

Wewers MD, Herzyk DJ (1989) Alveolar macrophages differ from blood monocytes in human IL- I beta release. J Immunol 143:1635-1641

Yamauchi K, Martinet Y, Crystal RG (1987) Modulation of fibronectin gene expression in human mononuclear phagocytes. J Clin Invest 80:1720-1727

Young DA, Lowe LD, Clark SC (1990) Comparison of the effect of IL-3, granulocyte-macrophage colony-stimulating factor and macrophage colonystimulating factor in supporting monocyte differentiation in culture. Analysis of antibody-dependent cytotoxicity. J Immunol 145:607-615

Zaiss M, Krause SW, Kreutz M, Andreesen R (1991) Lymphocyte-mediated inhibition of human monocyte to macrophage maturation in vitro. Proceedings of 5th Annual Conference of the Upper Rhine Universities on the Macrophage, Strasbourg/France, abstract 100 
Zembala M, Uracz W, Ruggiero I, Mytar B, Pryjma J (1984) Isolation and functional characteristics of $\mathrm{FcR}^{+}$and $\mathrm{FcR}^{-}$human monocyte subsets. J Immunol 133:1293-1299

Ziegler-Heitbrock HWL, Ströbel M, Kieper D, Fingerle G, Schlunck T, Petersmann I, Ellwart J, Blumenstein M, Haas JG (1992) Differential expression of cytokines in human blood monocyte subpopulations. Blood 79:503-511

Zwadlo G, Bröcker E-B, von Bassewitz D-B, Feige U. Sorg C (1985) A monoclonal antibody to a differentiation antigen present on mature human macrophages and absent from monocytes. J Immunol 134: 1487-1492 